\title{
Pioneers of "Dawnism" in Victorian Desert
}

\author{
Bahee Hadaegh \\ Shiraz University \\ bhadaegh@rose.shirazu.ac.ir
}

Doi:10.5901/mjss.2015.v6n4s2p340

\begin{abstract}
Arnold more than any other Victorian writer sums up for the reader the most typical qualities of the age. He shows the movement of thought in man in relation to the age. Arnold depicts the intellectual, cultural, religious and literary confusion of the age and calls it the "darkling plain. Throughout Arnold's poetic career he tries to connect internal integrity with the social lives of men who are alone in an alien world. "The Scholar Gipsy" brings a sense of contemplation back to the frozen minds of the Victorian Utilitarianism. Although the images of hopes in "The Scholar Gipsy" done by the visionary quest and the Tyrian Trader put an end to the life-long doubt-stricken Victorian men, they are only the demonstrations without any palpable, real application in the wasteland of the age. Sohrab in Sohrab and Rustum is a servant of God who struggles to enter the territory of his father. It is his own lost origin to which he enters and consequently finds peace and joins the 'All.' Here, Sohrab is the son who is under the ageis of Thomas Arnold, the father, a triumphant practical spirit guiding the inhabitants of the darkness to the light. If "The Scholar Gipsy" is the renovation of man's spirit from the uncertainty through the suggestion of a vision, and a "beacon of hope.' Sohrab and Rustum is Arnold's achieved vision and the real capture of the genuine self through the open involvement of the committed traveller in the way of perfection.
\end{abstract}

Keywords: Victorian Desert, Mathew Arnold, Dawnism, "Sohrab and Rustum"

\section{Introduction}

The cultural, literary, religious and intellectual confusion and ignorance, that are going on in the "darkling plain" are typical of the Victorian age and they can be traced in the works of other Victorians. The chief element responsible for the materialistic desires was the change of feudal system to democracy and the shift of power from aristocracy to middle class people. They found that they were capable to reach the highest degrees of progress. "Work" became the dominant watchword and Smiles (1965) in his life in London says, "life was action, not talk. The speech, the book, the reviews or newspaper article was so much force-expended force lost to practical usefulness" (II, 265). Very soon overwork led to weariness and unrest; and intellectual thought, broad scientific examinations, the collapse of faith and widespread laws of cause and effects caused paradoxical feelings of dismay and hope, happiness and anxiety. Tennyson in his In Memoriam shows the unstable situation of minds where there is no certainty to which man can appeal. This is the very reason why Carlyle wrote the story of Teufelsdreckh who is struggling in a world of uncertainties. Victorian victims can be recognized as isolated, alone, and nostalgiac creatures suffering from the melancholic phenomena which resulted in their ineternal conflicts. In the Victorian melancholia there seems no ultimate aim and, as a result, there remains a sense of frustration, isolation, despair, and a pale hope for a unifying belief. In his Sartur Resartus Carlyle(1969) points, "A feeble unit in the middle of a threatening Infinitude. The men and women around me, even speaking with me, were but figures .... In the midst of their crowded streets, I walked solitary" (163). Victorian age witnessed the widespread influence of the higher criticism of the Bible that created religious doubt and unrest. Victorians were proud of change, welfare and progress which are more material than spiritual.

Reflectively, against this background, Arnold reveals his own sensations about Victorian melancholia in his "Scholar Gipsy":

for early didst thou leave the world. . .

Free from the sick fatigue, the languid doubt, which much to have tried, in much been baffeld, brings.

O life unlike to ours!

Yes, we wait it-but it still delays,

And then we suffer ... 
from Shakespeare who in King Lear refers to the word "darkling" and then Keats uses it in "Ode to the Nightingale" and applies it to the moment when he loses his half poetic self and returns to the world of reality with which he has no affinity. According to Jerome Hamilton (1964), perhaps more insistently than any other critic Arnold demands moral values and is the severe critic of Victorian inflexibility and high seriousness (26).

Darkness is present in this plain and there are fogs and swirling sands. It is a desert, hot and always barren of any fertility. The inhabitants of the "forest glade" pay their love to their mothers, queens, and nature and are in the mood of innocence belonging to the childhood which in "The future" represent themselves as:

\author{
A wanderer is man from his birth. \\ He was born in a ship \\ On the breast of the river of Time; \\ Brimming with wonder and joy \\ He spreads out his arms to the lights, \\ Rivets his gaze on the banks of the stream. \\ $(1-5)$
}

\title{
1.1 Research Method
}

Literature can be studied through various lenses; formalism is one of the many approaches that can be applied to any piece of literary work, it was first introduced by a group of Russian scholars in 1915, they "boldly declared the autonomy of literature and poetic language, advocating a scientific approach to literary interpretation" (Bressler 51). Regardless of the author's biography, they paid close attention to the structural features or form, asserting that the reason for the literariness of any text is the devices that are exploited to make literature different from everyday language. In order to look for the devices such as symbols, ambiguities and tensions that, lead to the meaning of the text, close reading was recommended. From the formalists point of view form and content are inseparable, because paying particular attention to the formal aspects of a text would directly contribute to the meaning.Under the scope of Formalistic approach some elements of Arnold's poems such as the title, persona selection, apparent symbols, and recurrent motifs which are in line with the theme of the poems will be analyzed. Formalists whose major focus is on "the autonomous nature of literature" declare that the best way of studying literature is literature itself. In order to have a better understanding of a text's meaning, formalists claim the text should be analyzed as "a self-enclosed, law governed system" (Bressler 51- 52). So, the elements and devices by which Arnold tried to convey meaning becomes important in this study as such elements are highly focused and in a repeated manner as a chain that no other critical approach would reflect any better understanding of the poems. One of the other elements which can help formalists to analyze the text, is the close reading of the characters. "Characters are the persons represented in dramatic or narrative work, who are interpreted by the reader possessing particular moral, intellectual, and emotional qualities. ..." (Abrams, 1939, 42). Other elements to be considered in this study are title of the poems, symbols and recurrent motifs. The major theme of the poems which is the different manifestation of the quest that the poetic personas reveal as pioneers of dawnism in Victorian darkling plain..

Arnold's letters, essays, and poems delineate a line of development resulted from his keen observation of the events of his time. He depicts man's integral struggle in the "darkling plain" to find his true, hidden self Arnold's poems reflect his attempts to prevail a true self that saves not only his own hidden self, but also those of other victims. Paul F. Baum (1958) believes, "Matthew Arnold was very much a man of the practical world and very much bound to cure its problems" (9). His line of development proves Arnold's final success to find a true self committed to construct the ruined Victorians. Sohrab and Rustum and Obermann Once More are examples of such a triumph. According to Culler (1966) both Sohrab and Rustum poise their lives by incorporating their opposites within themselves (211). This actually means the imaginative reason which Arnold tried to capture. He gives to his poetic ideal the toughness it needs for survival in the real world and gathers multiplicity to reach a world of unity. According to Culler, "Arnold seems to combine Victorian earnestness with Romantic agony to produce a puzzleheaded poetry in which he solves his personal problems and imposes his solutions upon the world" (75).

\subsection{Review of Literature}

In "Matthew Arnold and Saint-Beuve" Arnold Whitridge regards Arnold as moralist for whom literature is a matter of ethics (1938). There are critics who trace Arnold's similarities to the French works like Renan's "Essais de morale et de critique". John Harding's "Renan and Arnold" (1938) sees in both of them similar subjects concerning education, Hellensim, Celticism, and the like. 
Allott (1978) in his annotated edition of Arnold's poems emphasizes Goethe's influence on Arnold (17). It is true, however, that all these writers and philosophers influenced Arnold, but as Houghton (1988) believes they acted only as a source of inspiration (19). One can find out that Carlyle's Sartus Resartus influenced Empedocles, but as Arnold rejects his creed, the implication lies in Arnold's rejection of Carlyle's teachings.

A line of development is visible in Arnold's poetry. From his early Romantic poems to the end of the "Marguerite" poems where he leaves his beloved to find his soul in solitude, not in the society of his friends and his beloved, and finally in Sohrab and Rustum in which his ultimate committed soul ventures to present moral ideas to society. Elliot ( 1964 ) believes that Arnold's course of development depends on his moods which have their source in differentiated emotional currents which gave him a sense of deep oppositions throughout his works (178).

Arnold's developing phases lead him culminatingly to particular type of Hellenism. His poems are found to be unified complex myth which becomes visible through different characters, landscapes, and actions. Culler (1966) states, "The thought is the man, whether in his individual life or in human history, moves from chidlhood faith and joy, through a period of skepticism and understanding to a final synthesis that reconciles the two" (3). Dr. Abjadian (1995) believes that Arnold's Preface and his poems reveal his awareness of the chocking atmosphere of the age (7).

The sense of a divided self is felt throughout Arnold's works and this shows obviously the conflicting mood of a modern man in the "darkling plain", struggling with his true self and his masked one. In Plotinsky's view (1964) the central problem of all Arnold's poems is the "divided mind", but in his narrative poems, he seems to solve the problem. Arnold's basic starting point in his rendering poetic advancement is the criticism of the darkling plain" reflecting the Victorian age. In "Dover Beach" Arnold shows the dominant phenomena and Delasanta (1959), revealing Arnold's theme in the poem, says," The theme is the melancholy awareness of the incompatibility of the imaginative world and the world of Victorian reality (item 7).

One can find Arnold's indebtedness to Newman. In his letters Arnold confesses Newman's influence on him: ". .." no words can be too strong to express my interest which I used to hear you at Oxford, and the pleasure with which I continue to read you, writings now... (57). In "Poetry with Reference to Arnold's Poetics" (1829) Newman states:

Poetry recreates the imagination by the superhuman loveliness of its views, it provides a solace for the mind broken by the disappointments and sufferings of actual life; and becomes the utterance of inward emotions of a moral feelings, seeking a purity which this world will not give. (10)

Arnold takes pleasure in giving way to his emotions and present his "rebellion and rage" against the age in which Sohrab, for example, seeks a truth which the world "will not give". Frank Kermode in The Romantic Image (1957) declares, "The new age excludes Arnold, or rather he excludes himself from the new age" (9). W. Stacey Johnson (1961) identifies Arnold with Empedocles in his "dialogue of the mind with itself" (117). Tristram and Isuelt is another manifestation of the world of the conflicting "darkling plain". Tristram engulfed by the power of love is chained in a burning world. He is "Thinned and pale before his time" (I, 108).

Hillis Miller (1963) has a chapter on Arnold in The Disappearance of God. He states that Arnold is still criticizing his society of its cultural failings, but also waiting for a dawn to come (215)

\subsection{Objective of the Study}

This study shows that protagonists in Arnold's poems who suffer from the aridity of the age and undertake different possible ways, such as what madmen, slaves, quietists, and strayed revelers do, to find a healing power for their wounds caused by the empty world of Victorian era. Arnold's sequence of poems and his course of development reveal his maturer ways and his final goal which is his social duty.

The sense of utter suffering, the conflict of the soul and the uncontrollable strivings by men in Arnold's poemscome to make him the father of modernism responsible for the future split personalities of modern writers. Empedocles and Tristram are the best examples of suffering victims who struggle to answer their volcanic buried selves but fail to receive them and are fulfilled at the time of their deaths. In his letter to Clough Arnold (1996) says, "yes, congestion of the brain is what we suffer from ... . I always feel it and say it ... and cry for it life my own Empedocles" (130). Sohrab, on the other hand, is the successful protagonist who not only lives with his buried self but also brings the spirit of animation and nobility to the arid society. One can easily find that the battefield of Sohrab and Rustum with its barren life and fragmented Oxus changes to be a calm place with the sound of waves becoming a sea: 


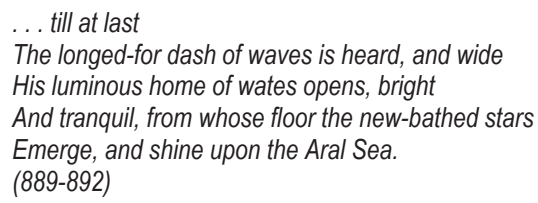

\section{Discussion}

The possibility of finding man's genuine self in the "Darkling Plain" of Victorian desert through awakening and discovering the dormant faculty of mind is introduced in the guise of an energetic quest, undertaken by Arnold's visionary Scholar Gipsy. "The Scholar Gipsy" suggests a glimmer of hope which has the potentiality of change and creating a prosperous future. This suggestion is also manifested in "The Future." This is the motive which the Scholar seeks and the speakers invoke a dream to prepare an appropriate ground for a better life:

Haply the river of time

May acquire; if not the calm

Of its early mountainous shore,

Yet a solemn peace of its own. ("The future" 71-8)

The revelation of a nobler inward life is what Arnold points out in "The Scholar Gipsy" through the suggestion of the quest. He introduces the suggestion of a positive change which is the first step in changing the doubtful obscurity of a hopeless generation. The emergent introduction of a positive change is something which Arnold finds by the Scholar's quest, hoping that the alienated Victorians could hear and see a dim ray of hope and feel its power within themselves:

\section{Thus feeling, gazing, might I grow \\ Compos'd, refresh'd ennobled, clear; \\ To work or wait elsewhere or here! ("Awish" 50-4)}

The insistence on the possible fulfillment of hope is shown by inviting people to seek actively for their genuine selves in the "darkling plain." In order to make men believe such a possibility, Arnold describes the image of his Utopian model in the final simile of the Tyrian Trader at the end of "The Scholar Gipsy." After his positive assertion of hope for the future, Arnold needs to show an abstract model of prosperity for which he prescribed the immediate quest. The transfiguration of an imaginary quest to a more real abstract image confirms the possibility of success. After seeing such a brief demonstration of a man determined to find the buried self, naturally a note of optimism emerges: "How fair a lot to fill/Is left to each man still" ("A Summer Night" 91-2).

From now on, the purposeless people whose lives had been for long without any aim are suddenly pushed aimfully to look for the genuine self. It is the natural by-product of witnessing the Utopia even if it is in a vision or after observing an abstract model. The sense of optimism and the emergence of a purposeful agent are also present in the vision in "Obermann Once More" in which the poet, who speaks to Arnold in a vision, ends his message hopefully:

The world's great order dawns in sheen,

After long darkness rude,

Divinelier imaged, clearer seen,

With happier zeal pursued. (295-6)

R. A. Foakes (1958) considers Arnold's technique in showing his abstract model of hope, as rhetoric of assertion in which he urges men to attain their genuine selves in the "darkling plain." As Foakes declares, "Arnold helps men hope for a new-made world" (18-19).

After finishing "The Scholar Gipsy," in a letter to Clough, Arnold says, "but what does it do for you?" (146) Paul Edwards briefly comments on this sentence and claims that "Arnold meant to insist on the business of learning and knowledge in his "Scholar Gipsy." What he does is to awaken only man's inward potentiality and persuade man to seek for his genuine self. But after writing "The Scholar Gipsy," Arnold feels the necessity of action after the recognition (63).

After the abstract image of assertion conveyed through the Tyrian Trader, the third phase of Arnold's stage in finding the genuine self begins. Here, man purposefully gets involved in an active search and prepares himself to fight 
against every possible block present in the battlefield of the waste. Now, he is bound more energetically to find his lost identity and he ventures to destroy everything which wants to stop him in the world of the Victorian social selves. Man is seen crying: "On, to the bounds of the waste,I On, to the city of God" ("Rugby Chapel" 206-7).

In his Culture and Anarchy, Arnold (1960) says, "Religion says: The Kingdom of God is within you; and culture, in like manner, places human perfection in an internal condition" (47). Arnold tries to awaken that "Kingdom" within man through a visionary quest and the demonstration of its final result. But the internal awakening is not enough; it should be guided to some meaningful function.

While "The Scholar Gipsy" is the revival of the internal "Kingdom of God," Sohrab and Rustum is a step forward, following that internal recognition.

This study shows how Arnold presents his committed character, Sohrab, who is going "On, to the bounds of the waste" seeking actively his genuine self. While the absolute Utopian world of the Tyrian Trader briefly introduces a successful man seeking his true self, Sohrab endeavors to grasp it. The process of the struggling of the Tyrian Trader is not presented at all, and Arnold swiftly passes from it to the final border line when the Trader is shown passing the "strait" witnessing the fresh air of the Atlantic waves. On the other hand, Sohrab's process of struggle is shown in details connoting the intensive influence of the previous assertion and the manifestation of the spirit of confrontation with the waste.

In Sohrab and Rustum Arnold relies on features like movement, energy, youth, and action to make the theme of the quest prevail more concretely. It becomes palpable for every reader who faces openly the decisive, energetic spirit of the quest in finding man's inward sufficiency through direct confrontation with the "darkling plain."

From the very beginning of Sohrab and Rustum, one can see a new atmosphere as a result of that decisive, fighting spirit. The active, optimistic spirit of the quest after "The Scholar Gipsy's" positive assertion of hope and its final recognition, is dominant throughout Sohrab and Rustum. It has even changed the pole of stress from one stage to another. There are lines in the poem in which Arnold explicitly confesses that the mood of passivity, hesitation, doubt and evaluation has been completely ended as a result of a strong belief in hopeful prospections of the speaker of "The Scholar Gipsy;" and now is the day of bold action, immediacy and bravery in finding one's genuine self; it is the time of heroic confrontation with the "darkling plain."

Gudurz is seen in the tent-door of Rustum inviting him to fight; he openly refers to the point which is the center of attention throughout the poem:

"Not now! a time will come to eat and drink,/ But now to-day; today has other needs" (208-9).

The repetition of the word "to-day" connotes the shift of mood and the need which Rustum ignores. Gudurz's speech refers implicitly to the fact that a day will come when men celebrate their victory over their social selves, but today is the day of action and fighting in addition to a direct involvement in the "darkling plain" to find the genuine self.

Due to its decisive theme, the stage of the poem's world is different from that of "The Scholar Gipsy." The poem begins with daybreak, when the first light of the day fills the scene. Thus, morning comes with its own activity, and darkness, which is the symbol of rest, waiting, and ignorance, has gone. The boring atmosphere of fogs which suggest man's inward blindness, has not been removed yet, perhaps because of Rustum's ignorant self. "And the first grey of morning filled the east, I And the fog rose out of the Oxus stream" (1-2).

There are other references to the morning light in "Obermann Once More" and in "Stanzas in Memory of the Author of Obermam" which are also suggestive of the appearance of a different stage. The reference to the light in these poems, as in Sohrab and Rustum, can be considered as a vital message of the moment.

Despair not thou as I despaired,

Nor be cold gloom thy prisonl

Forward the gracious hours have fared,

And see! the sun is risen!

("Obermann Once More" 281-4)

In "Obermann Once More" one can see Arnold welcoming the breaking light:

And glorious there, without a sound,

Across the glimmering lake;

High in the Valais-depth profound,

I saw the morning break. (I. 345-8) 
Hugh Kingsmill (1969) calls it a "phase of dawnism." He believes that both Sohrab and Rustum and "Obermann Once More" show a departure from depression and ennui to a creative, optimistic poetry (97).

Throughout the night, the ghost of Obermann appears on the mountain and insists that the tempests are gone, the new day has come, the sun is rising and the ice is melting. The time of vision is ended and what is left is only action with the connotation of hope and prosperity.

Arnold has passed through the period of dissatisfaction and has come to the possibility of hope and the beginning of a new stage. It is true that Arnold was scanning his way in some of his early poems to a practical quest to find the genuine self in the burning desert," but he completes the quest in Sohrab and Rustum.

Arnold moves from dream to inspirating reality. He feels that things are better than they were, and there must be no more joy in meadows, for it is the time of action. So, Arnold in Sohrab and Rustum seeks to reinforce spiritually and realistically his more practical endeavors to cut through what he had merely asserted.

He works, as Sohrab does, to see the ideal world realized. That is why Sohrab decides with his alert mind to act hopefully. He is like Obermann here who affirms that "Henceforth man/ Must Labour" (185-86).

Sohrab appears at the very beginning restlessly waiting for the combat. It is mentioned that everyone is asleep in his camp except Sohrab: "Sohrab alone, he slept not, all night long/ He had lain wakeful, tossing on his bed" (5-6). Labour and commitment have occupied his mind preventing him to rest in the world of ignorance and passivity. The "dawn" of decision has come and he is determined to begin his quest of self-identity: "When the grey dawn stole into his tent/ $\mathrm{He}$ rose, and clad himself, and girt his sword" (7-8).

The active and decisive spirit of Sohrab, which suggest his wakeful breast, are in sharp contrast to the ignorant men around him, those who act as a foil for Sohrab to sharpen the intensity of his desirous heart. The Tartar camps are black gathering together like "bee-hives" on the "low flat of Oxus" connoting a calm and immobile life. It goes further to the climax of such a life when "Upon the thick piled carpets in the tents/ And found the old man sleeping on his bed" (24-5). The bed, rugs, and felts upon the thick piled carpets with an old man lying on them, suggest the immobility and fruitlessness.

Sohrab is young and wakeful; he sets to work and goes for getting counsel to calm his volcanic breast and his inward discontent. He acts as a mouthpiece of a movement, as a pioneer for the stage of "Dawnism," a practical involvement to find the genuine self.

Thou know'st me, Peran-Wisa! It is I.

The sun is not risen, and the foe

Sleep; but I sleep not; all night long I lie

Tossing and wakeful, and I come to thee.

(Sohrab and Rustum 34-7)

Sohrab has left the "forest glade" of his mother town in Aden-baijan and now he is passing his youth in the world of the "darkling plain." Actually he was once in Afrasiab's garden where he learnt the arts of fighting and got to maturity Afrasiab's garden is the woods to which the Scholar ran to find the lore of the Gipsies. It is a learning stage where the necessary lessons are taught and Peran-Wisa, being an old, moderate man, suggests the spirit of that experience. While the Scholar Gipsy is only seen in his learning stage, passing his times following the Gipsies, gathering flowers, and sitting by the brooks, Sohrab is seen at the end of this stage.

Afrasiab has allowed Sohrab to gather his experiences and find what he desires: "For so did King Afrasiab bid me seek" (37). Peran-Wisa is the gathered experience of Sohrab's learning stage. This spirit of experience is now asleep suggesting that there is no external outburst in gathering experiences without applying them to some meaningful purpose. The dialogue of Sohrab with Peran-Wisa in taking his counsel and permission seems to be the dialogue of Sohrab with his own learned spirit. He confesses that he has learned enough arts and has proved his aptness in finding what he lacked: "I have still served Afrasiab well, and shown,I At my boy's years, the courage of a man" (45-6). He continues to say:

This too thou know'st, that while I still bear on

The conquering Tartar ensigns through the world,

And beat the Persians back on every field.

$(48-9)$

Now, it is the time to seek energetically what he wants: "Go, I will grant thee what thy heart desires" (93). Sohrab here is another Scholar after the vision of the speaker when after a long time of experience and exposition to the 
imaginative world of the Gipsies, he turns to be purposeful: "Thou hast one aim, one business, one desire" ("The Scholar Gipsy" 152). Sohrab also, after being experineced in Afrasiab's garden, finds that the passive, hesitating life of experience and preparation has come to an end and it is time for him to "Labour" practically and achieve his quest: "I seek one man, one man, and one alone/ Rustum, my father; who I hoped should greet" (48-9). Sohrab continues to say: "Should one day greet, upon some well-fought-field/ His not unworthy, not inglorious son" (51-52).

"Some well-fought-field" clearly manifests Sohrab's insistance on action. Later on he also says, "but I/ will challenge forth the bravest Persian Lords" 955-6). His belief about the necessity of being recognized by his father is a motif repeatedly asserted to reinforce the fact that his energy, his courage, and his practical search must be recognized. Arnold wants to introduce the spirit of courage and practical involvement in the guise of Sohrab who is aware of his great mission and decides to handle it properly. Dr. Abjadian says, "he wants to be not in the ivory tower, but part of the waste, he proves that he belongs to that Victorian desert, and should have on active role here"( 415).

The internal unrest puts an end to the period of learning, and Sohrab feels that he must find his originality. He has been separated from his real lineage. He was born in Aderbaijan which is not his actual hometown, neither does he belong to Afrasiab's garden. His unrest is due to the lack of compatibility with the places in which he was born and brought up: "O Sohrab, an unquiet heart is thine" (65). He is so dear both to his mother and his friends; he is superficially happy and they love him very much:

\section{Can thou not rest among the Tartar chiefs \\ And share the battle's common chance with us \\ Who love thee. (65-7)}

Elsewhere Rustum summarizes Sohrab's life in Afrasiab's garden as "Thou art not in Afrasiab's gardens now/ With Tartar girls, with whom thou art wont to come" (460-1). Unfortunately, he does not feel at home there. The process of maturity in his learning stage in Afrasiab's Garden has helped him feel that he has been separated from his origin, from his father, and now he demands it. He has a positive notion of his father as the origin of man is naturlaly good and divine. Sohrab is in Tartar camps in the peak of Pamere connoting his internal energy and passion in finding his origin.

The hesitation and doubt as well as the fact that Peran-Wisa is so cautious to advise Sohrab to seek his father in "peace," delineate the phase of internal passivity which is finally doomed to failure. He confesses that, "In vain; but who can keep the Lion's cub/ From ravening, and who govern Rustum's son" (90-1).

As the opening of the poem begins by Sohrab's wakeful image and the reference to water imagery of Oxus suggesting movement and energy, the advancement of the Tartar horsemen into the open field is also accompanied by the rising of the sun clearing fogs from Oxus: "The sun by this has risen, and cleared the fog/ from the broad Oxus and the glittering sands" (104-5). It is the beginning of Sohrab's active, conscious involvement to find his origin, his father.

The activity witnessed among the Tartar men helps the reader find that the period of passive meditation of "The Scholar Gipsy" in its learning stage of the woods has been replaced by a practical involvement which is a direct result of that imaginative preparation.

Haman, who is now the head of the Tartars after the old Peran-Wisa, is seen in his pick of youth, energy, and practicality; "Haman, who next to Peran-Wisa ruled/ The host, and still was in his lusty prime" (108-9).

The horsemen stream into the field, and the pace of movement is going to be faster as the similes suggesting action intensify the moods. These similes not only mingle with the great action of the poem, but also externalize or objectify the internal energetic states of the character who dares to seek his genuine self. It reflects Sohrab's knowledge that he should have an active role in the Victorian desert and should put an end the ignorant mood.

The first simile is the simile of the long-necked cranes that stream over the Casbian sea and are southward bounds. They are migrating birds that travel from one part of the country to another. They are associated with an active life. Fixity is not applicable to them and the Tartar troops are similar to them as they are also going southwards.

The demonstration of the Tartars as the cranes justifies their internal moods. They are often refered to with epithets like temperate, light, wild, unkempt and bright which imply the notion of activity, decision, passion, and boldness. Arnold ascribes the characteristics of shepherds to most of them. In spite of their spiritual wakefulness, they are the image of daywork. Peran-Wisa, in spite of his being old, threads the "Tartar squadrons to the front" and he himself is described as a shepherd wearing a white cloak and a sheep-skin cap with a ruler's staff in hand. It suggests that the practicality of this side is constructive aiming at a significant end which is finding the truth. They accompany Sohrab who is bold in finding his origin. Sohrab and his friends are the embodiment of a positive action which has a spiritual background.

Unlike the Tartars whose moving spirit and leading energy are impressive, the Persians are depicted as motionless 
and without any motives to do anything constructive. While the Tartars are similar to the travelling birds, the Persians are like the Pedlars who are thirsty but incapable of slacking their thirst with "sugared mulberries." They are not only the spirit of laziness but they are recurrently ignoring their needs.
But as a troop of pedlars, from Cabool,
Cross underneath the Indian Caucasus,
That vast-neighboring mountain of milksonw;
Crossing so light, that, as they mount, they pass
Long flocks of travelling birds dead on the snow
Chocked by the air, and scarce can they themselves
Slack their parched throats with sugared mulberries.
$(160-6)$

The spiritual laziness of the Persians has been attributed to their physical thirst. They scarcely refresh themselves out of fear. They ignore their urgent need which is water. Persian troops are the representatives of the materialistic Victorians who ignore their spirituality and do not enliven it with the inspirating water of virtue and active quest. There is no activity on the side of them. They are slow, single walking men:

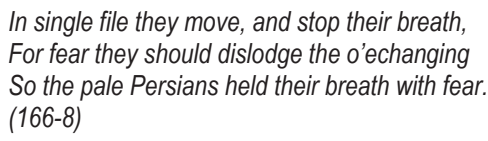

On the contrary, the Tartar troops are shown as drinking milk of mares suggesting their attempts to refresh themselves. They are not ignorant of their essential needs:

\section{First, with black sheep-skin caps and with long spears, Large men, large steeds; who from Bokhara come And Khiva, and ferment the milk of mares Next the more temperate Toorkmuns of the south,}

Light men and on light steeds, who only drink

The acrid milk of camels, and their wells. (119-215)

In Culture and Anarchy, Arnold (1960) alludes to Sohrab's challenge and his entrance into the barren field which can be considered as bringing sweetness and light to the barren and black situation of the opposite side (126). The color of the faces in the Persian side is pale in sharp contrast with the lusty, passionate Tartars who ride lightly and energetically onto the field. They are afraid of finding their essential needs and find it destructive. Arnold beautifully connotes the lack of venture and the boldness of the ignorant Victorians who do not dare to seek energetically their genuine selves.

On the Persian side the focus is on the world of hesitation, caution, fear, separation, and old age which are different aspects of one feature, the lack of action. It is a foil for the committed Sorhab who challenges to bring the spirit of life back to this wasteland. Arnold wants to reinforce the fact that the stage is completely changed and the life of such people is in its end.

Rustum whom Sohrab seeks is isolated and lives a lonely life. He has been a powerful champion but his relationship with the younger generation has been disconnected. He is angry now and has isolated himself from the rest, living in his own black tent. Gudure openly confesses that Sohrab is "young, and Iran's chiefs are old/ Or else too weak; and all eyes turn to thee" (216-17). Rustum is seen in his own solitude ignoring the life outside: "aloof he sits/ And sullen, and has pitched his tent apart" (179-80).

On his first appearance, Rustum emerges in his gloomy, lazy mood, reluctant to have his breakfast: "Rustum; his morning meal was done, but still/ The table stood before him, charged with food" (169-7).

The falcon on his wrist is the representative of a life of a hunter and the fact that Rustum is like the falcon who is not involved in a practical life. Arnold distorts Rustum's heroic grandeur and practicality by depicting him not as a hero who fights, but a hunter who is just looking and waiting for some defenceless creature.

Rustum had certainly had his own heroic days when he was young, but now his heroic days are gone. The insistance on the immobility of Rustum implies that the age of old generation is dead and it is now the outburst of the new 
stage, the stage of practical Sorhab.

The following lines suggest that the Victorian victims must desperately accept the change of the stage:

Errs strangely; for the king, for Kai Khosro

Himself is young, and honours younger men,

And lets the aged moulder to their graves

Rustum he loves no more, but loves the young-

(223-6)

The fact that Kai Khosro, pays no attention to the old and respects the young, proves the dominion of the new age and Sohrab's final gratification to find the genuine self through his youth and venture. The Victorian victims find their fault in sitting idle.They confess their failure and a sense of loss:"For what care I, though all speak of Sohrab's fame?" (227)

Really Sohrab is another Rustum who is only aware of his own beating desires and listens to the promptings of the buried life in the "darkling plain" while Rustum willingly sets it aside and knowingly leaves a practical venture leading his solitary life. When lamenting at Sohrab's final breathings Rustum points to this fact:

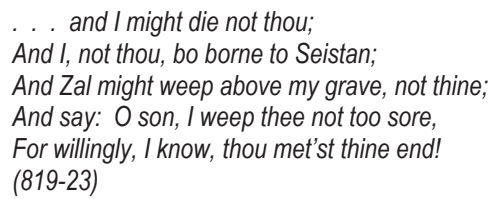

Rustum is the perfect model of the Victorian man with the stress on his ignorance. He has tragically left his old father, Zal, in his hometown Seistan, clearly connoting the image of an ignorant Victorian who knowingly ignores his consciousness of the buried origin and his own breast. However, he longs for such a power as one can see him wishing for having a brave son:

For would that I myself had such as on,

And not that one slight helpless girl

A son so famed, so brave, to send to war

(228-230)

Rustum himself is tired of his present life in the passive wasteland and longs for his father land. His desire for power, venture, and energy can be considered as a foretelling of a changing mood. He shows his inward compatibility with his father land and it is the unconscious beatings of his heart, "And I to tarry with the snow-haired Zal" (233). It is his origin which summons but he is bewildered in the "darkling plain."

Sohrab on the other hand, has not knowingly separated himself from his father in the sense of his origin or his true self. As we know he is born in his mother town without witnessing the presence of his father. He has not alienated himself from his fatherland knowingly; rather, he ventures willingly to find his origin. He has not been gratified only by gathering experience in Afrasiab's garden. He has courage to save his lost identity, his father, his genuine self; while Rustum does not dare to protect his father, his origin, or his genuine self. Zal is presented under the attack of foreigners:

My father, whom the robbers, Afghans, vex,

And clip his border thort, and drive his heards,

And he has none to guard his weak old age. (233-5)

Rustum knows the emergency of protecting his father (genuine self), but he is like a slave and quietist who leads a solitary life. The materialistic and chaotic Victorian system captures the true, divine, and spiritual genuine self which is introduced here as Zal, the father figure. The Victorian victim, like Rustum, is powerless to protect it. The fact that Rustum does not know that he has a son and he refers to his child as a girl suggests lack of faith, lack of belief in his own powerful potentiality.

Despite Rustum's ignorance of his father, origin, and the true self, the younger, energetic Sohrab decisively searches for him. He trusts his inward impulse and the youthful openness and willingness to trust his own instinct and decisive heart is the main focal point which Arnold insists in Sohrab and Rustum.

James Najarian (1996), who stresses on the youthful energy manifested in Sorhrab, says, "Sorhab is Arnold's 
desire to a self-mastery over his dandified Keatsian Arnold to reach a masculine, practical man" (1 of 2). He continues to claim that Sohrab's quest for his father is Arnold's courageous quest for a stronger identification and his last victory is due to his paternal recognition. The vigorous and easy spirit of the youth is freshly presented as a foil to the questioning, hesitant nature of the Victorian victims.

Every image on the side of Rustum implies the death of an ignorant life. The diver image suggests the peak of passivity. The disability and death found in passive, solitary life of Victorian men once more appear in the image of the pale wife who is shown waiting. The pale color of her face points to the failure of such a stage. She is shown as weeping on the sandy shore, implying the lamentation over the ignorant stage:

\section{And dear as the wet diver to the eyes \\ Of his pale wife who waits and weeps on shore, \\ By sandy Bahrein, in Persian Gulf, (284-6)}

It is going to be clearer in the following line in which Arnold explicitly portrays the agony of the whole ignorant stage:

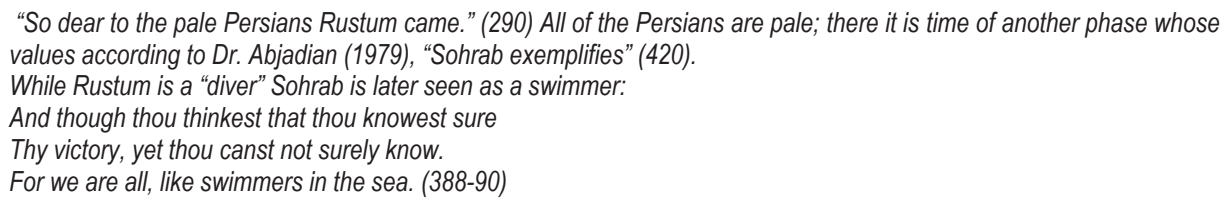

While Rustum is now old and can do nothing except waiting. Sohrab believes in active struggle to find his genuine self. He insists on his power which is a mouthpiece for what Arnold cherishes as the true policy: "I am no girl" (381).

Sohrab breaks the immobile atmosphere of the age and is a forerunner of another stage. Arnold repeats a sentence three times to support the spirit of the change: "He has the wild stage's foot, the lion's heart" (215). He comes decisively and armed to put aside every obstacle in his way towards the desired goal. He is among a field of corn with half reaped standing corns. Sohrab's entrance to the battlefield in the season of harvest reveals his job as a reaper who comes to cut what he has already sown in his days of gathering experience and maturity in Afrasiab's garden. He is now in Autumn with half cut corns meaning a mission not done completely. Sohrab is on his mission which is going to be done completely while he has done half of it by entering the new mood of practice to fulfill his breast.

From the very beginning Sohrab senses that his opponent is his father Rustum: "Surely my heart cried out that it was thou/ When I first saw thee, and thy heart spoke too (711-12). He answers to the call of his genuine self which leads him to submit himself to Rustum: "Art thou not Rustum? speak: art thou not he?" (345)

Elsewhere Sorhab says:

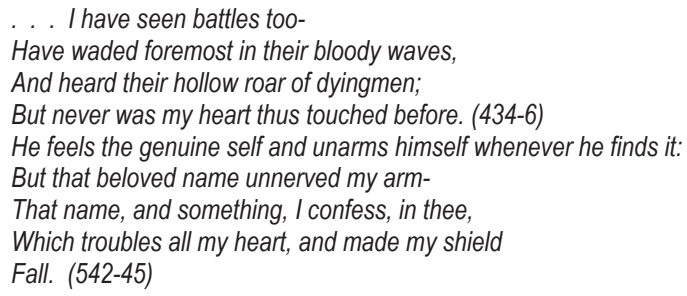

Najarian believes that the allusion to Hyacinthus clearly shows Sohrab's love for his father which in turn tells of Sohrab's love for his origin. He is a lover of genuine self (2 of 2).

Sohrab's active quest is stopped when he finds the object of the quest, the genuine self or his origin. But Rustum from the very beginning denies his presence knowingly: "Man, who art thou who dost deny my words? (655)

Sohrab's actions, courage, and practicality aim at finding his lost identity just in sharp contrast with Rustum's actions which are negative and planned to protect himself from self-recognition. Rustum denies his own identity. He does not put forward one step to accept the truth of Sohrab's identity.

Rustum's first advice to Sorhab connotes a message of "not being". He wants Sohrab to be submissive: "And fight beneath my banner" (332). He appears as a block, huge column "planted on the sand" suggesting protection and 
defiance against any awakening raptures. He is refered to as a "giant figures" as a guard to defend the wasteland: "Sole, like some single tower, which a chief/ hath builded on the waste in former days against the robbers" (336-7). He says explicitly: "Let me hear thy hateful voice no more!" (459) and light.

The old Victorian creeds of materialism and unpoetic temperament have made Rustum resist against sweetness

Rustum is not only passive and ignorant himself, but also preaches Sohrab not to fight against the Persians. A close study of the lines supports the fact that every step Sohrab takes is to put obstacles aside and to keep himself alive in order to be fresh to continue his mission. Dr. Abjadian says, "throughout the poem there are references to Heaven, life, love, honesty, and truth by Sohrab" (419). Sohrab's springing aside also suggests his protection against destructive elements while Rustum's "not being" mood is against constructive elements.

Sohrab is light and youthful suggesting energy and mobility. He is aware of the danger in the "darkling plain" and quickly protects himself from the spear: "Sohrab saw it come,I And sprang aside, quick as a flash" (201-2). Rustum's image, on the other hand, suggests the hostile atmosphere of the "darkling plain" and the decline of his power. He carries iron plates, spears, and club which prevent him from any light, quick action. The quickness and enlivening spirit of Sohrab is accompanied by water imagery while Arnold associates the Persians with fire, a destructive elements of death. M. Amiri believes that the dominance of Sohrab's active stage has been mentioned earlier in the poem when Arnold talks about his courage and power which made Persians fearful and trembling. The ignorant side of Victorian culture is introduced in its weakest point which is going to be replaced with an active venture (27).

Sohrab's undermining his opponent suggests his optimistic view of his victory and his hope to change the ignorant "darkling plain" to a wakeful "forest glade":

Boy as I am, I have seen battles too-

Have waded foremost in their bloody waves,

And heard their hollow roar of dying men.

$(432-5)$

Sohrab's drawing sword over Rustum is his bold rush to remove the obstacle in the way of finding his genuine self. He is intended to defeat Rustum when he finds him an obstacle in his way to reach the genuine self. In a letter to Jane, Arnold writes, "Man's purpose is to nuture the sense of joy, to nourish the forces that make for freedom, and to resist, wherever he meets it, whatever degrades and causes pain" (149). He fights while encouraged by a great motive and he anticipates a great change and the appearance of the glimmering sea.

The conflict between the practical involvement and hostile ignorance is not a simple task and Arnold calls it "unnatural." The scenery suggests its harshness. It is as dangerous and horryfying as the "sandy whirlwind," "rising wind," and "chrashing trees." But there is finally a suggestion of peace and reconciliation: "And the sun sparkled on the Oxus stream" (489). The revolutionary outburst predicts the final change in the "darkling plain" and its inhabitants. The climactic darkness, thunder, and renting lightning bear the babtismal seeds of rain in themselves which anticipate a great change.

The terror and wonder existing in such a revolution does not frighten Sohrab who is decisive to find his own oring. Besides he wanst to introduce sweetness and light in the "darkling plain."

The committed Sohrab stops fighting when he hears the name of his father. It seems that he has done his mission. His death can be considered as a permanent rest after his great heroic resistance. The breaking sun suggests fulfillment after his inward chaotic darkness: "And then the gloom dispersed, and the windfell/ And the bright sun broke forth, and melted all the cloud; (522-3).

Sohrab openly reminds us that Rustum, not his enemy, has killed him. This means he sacrifices his life to his desired origin, his true self. "No! Rustum slays me, and this filial heart" (543).

From now on fighting ends, the pace of the poem slows down; it is a preparation for Rustum's inward change. After Sohrab's deadly wound, the token of his mother and grandfather make Rustum recapture his lost memory. Now, the boastful, proud, alienated man thinks of his own childhood with stress on the life of a "Shephered," the life of constructive action, moderation, and inward wakefulness. The spirit of a true practicality overwhelms him: Abjadian says, "he becomes a shepherd himself" (421). Earlier in the poem one could find Rustum in his passive, alienated, gloomy and heavy isolation but now there occurs a change of joy, rapture, lightness, and constructive action;

He is washed by stars and we witness the coming change: 
The Shepherd from mountain-lodge descries-

(618-20)

The "darkling plain" of the Victorian society made Rustum forget his own self and Sohrab's speech at the time of his death awakens his dormant memory. Arnold moves step by step towards the climactic self-recognition. After Sohrab's insistance on his being Rustum's son, he finally understands and reaches the truth. By this time Rustum finds that the child is a son, powerful, courageous, and bold. This is the recognition of the alienated Victorian man of an active, powerful, strong genuine self. Rustum is seen ultimately as refering to his own breast; he finally touches the life-long ignored buried self:

\section{He spoke; and all the blood left Rustum's cheeks And his knees to ttered, and he smote his hand Against his breast. (661-3)}

Sohrab's venture to verify his power as a son and to announce his energy to his father is once more shown when he is crawling to where Rustum lay. He makes him nearer to his father which means the insertion of action and courage to passive boastfulness: He touches him: "His arms about his neck and kissed his lip" (695).

Sohrab grants the precious wakefulness to Rustum: "Trying to call him back to life" (697).He wants Rustum to take his head and wash them with tears connoting the insistance on accepting courage and he accepts it, "And kissed him" (723).

Sohrab's insistence on being accepted as Rustum's son is the other side of the mission which he undertook. He has not only ventured to find his own lost origin in his lost father, but also after finding him, makes Rustum also acknowledge the truth. In this case his mission is not two dimentional, but deep and dynamic. Culture and Anarchy justifies Sohrab's second desire and, according to Bateson (1939), this is what Arnold planed to reveal in Sohrab and Rustum:

Perfection, as culture conceives it, is not possible while the individual remains isolated. The individual is required, under pain of being stunted and enfeebled in his own development if he disobeys, to carry others along with him in his march towards perfection, to be continually doing all he can to enlarge and increase the volume of the human stream sweeping thither wards. (49)

The acceptance of Sohrab by Rustum is the acceptance of the spirit of wakefulness and courage to find the genuine self. Sohrab pleas Rustum to carry his corpse to Seistan, the land of his origin and that of the father figure Zal. He has not only found his origin (Rustum) but wants Rustum to find his own origin (Zal) too: "And quit thee host, and bear thee hence with mel And carry thee away to Seistan" (898-99).

Or "But carry me with thee to Seistan" (787).

Now Rustum is affected and confesses his previous life as a bad one: "What should I do with slaying any more" (807).

He confirms that he is going to go there, the father land "Soon be that day, my son, and deep that sea!" (835). Rustum at this time is actually witnessing the passionate blood which is flowing from Sohrab's side. It is the life which Sohrab lets go and Rustum is taking. He is laying besides Sohrab to regenerate himself by the energy of Sohrab's blood.

In a letter to Clough, Arnold (1996) reveals the strong impulse towards activity, "still, nothing can absolve us from the duty of doing all we can to keep alive our courage and activity" (122). Sohrab, following this desire, draws the spear from his side and let his enlivening blood refresh Rustum's courage and keep his energy alive. "So thou mightest live too, my son, my son!" (815).

The "far seen Pillar" simile suggests the theme of keeping one's courage alive. Sohrab endeavours to make the spirit of movement towards the genuine self known and universal. He wants to erect a pillar of remembrance to give continuous hints to the blind victims of passivity and ignorance:

And thou must lay me in that lovely earth,

And heap a stately mound above my bones,

And plant a far-seen pillar overall.

That so the passing horseman on the waste

May see my tomb a great way off, and cry

Sohrab, the mighty Rustum's son, lies there.

(787-792) 
Really, it is huge pillar of the strong genuine self planted on the origin land of Zal, the father figure who is the symbol of the forgotten truth.

By taking Sohrab's advice and life, Rustum accepts the spirit of courage (his son) and sets to return to his father land. The barren Oxus consequently hears the longed for noise of waves and moves towards its father, the Aral Sea:

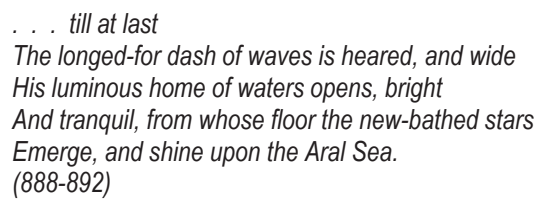

The fact that Sorhab's seal on his shoulder turns to be like porecelain vase pricked by a workman in Pekin, beautifully shows what Arnold desired from the very beginning. It is not merely a piece of art but a production of a noble work. Sohrab is a blend of both mental alertness and practical venture. He is the embodiment of the peacemakers in the Bible "who find not only peace in themselves, but in others" (James 3: 18)

The image of the workman in Pekin is analogus to the shepherd image palpable by Rustum too. Rustum turns also to an alert agent who ventures finally to a practical travel to his fatherland. It is what Arnold also captures in "Obermann" by refering to the "shepherd's gard" (II. 64-65).

\section{Conclusion}

By stressing on physical venture and alert mind, Sohrab and Rustum aims at showing in details the process of movement, and energy to find the genuine self. It begins with the moving imagery of Oxus and ends at its movement towards the Aral Sea. It begins with life and ends with life. Andrew Lang considering the enlivening function of this peom says, "Sohrab and Rustum does more for culture than a world of essays and reviews" (99).

While Empedocles on Etna turns on the first switch of inward revolution, and "The Scholar Gipsy" reveals a possibility of that revolution through the vision of a quest, Sohrab and Rustum applies the inward revolution to the outward practical world and turns other dormant minds to manifested outburst and wakefulness.

\section{References}

Abjadian, Amrollah. (1979). "Arnold and Sohrab in Wasteland." Victorian Institute Journal, 8, 61-79.

Abrams, M.H. (1939). The Glossary of Literary Terms. Cengage Learning.

Allott, Kenneth, (1978). Matthew Arnold (Writers \& Their Background S.) Unwin Hyman.

Amiri, M. (1977). Sohrab and Rustum, with Notes and Introduction. Shiraz University Press.

Arnold, Matthew. (1960). The Complete Prose Works of Matthew Arnold. Ed. R. H. Super: Michigan University Press.

(1902). Essays in Criticism. Superin University Press.

- (1996). The Letters of Matthew Arnold. Ed. Cecil. Y. Lang. Charlottesville: University Press of Virginia.

. (1968). The Letters of Matthew Arnold to Arthur Hugh Clough. Ed. Howard Foster Lowry. New York: Russell.

--. (1989).Notebooks, Sketchbooks, ETC. Ed. S.O.A. Ullmann, Michigan: Michigan University Press.

(1923). Unpublished Letters of Matthew Arnold. Ed. Arnold Whitridge. New Haven: Conn.

(1989). The Yale Manuscript of Matthew Arnold. Ed. S.O.A. Ullmann. Michigan: Michigan University Press.

Bateson, F. W. (1939). "Arnold's Some Views." English Poetry and the English Language. London: Oxford University Press.

Bressler, Charles. (1999). Literary Criticism: An Introduction to Theory and Practice.Prentice Hall.

Edwards, Paul. (1962). "Hebraism, Hellenism and "The Scholar Gipsy." Durham University journal 45, 21-7.

Kingsmil, Hugh. (1969). "Arnold's Dawnism." in Matthew Arnold. Michael Thorpe. London: Montague House.

Najarian, James. (1996). "Curled, Minion, dancer of Sweet Words, Keats, Dandyism, Sexual Indetermincay in Sohrab and Rustum." Journal of Literature Arts 35, 1-3. 